The use of this mixture as a routine is good because simple, but it has only its simplicity to recommend it, and if safety can be added to simplicity by the "simple complication "of adopting the "open ether" method, what grounds does the rejection of a good working theory give for condemning the improvement in method?

To adrocate any method of giving chloroform (to give $\mathrm{C}_{2} \mathrm{E}_{3}$ is to give chloroform) which does not provide for a diminishing dose is in these days a retrogression, and in so far self-condemnatory. And this for two reasons, each becoming almost daily plainer and better understood. These are: (1) the not infrequent occurrence of "status lym. phaticus"; and (2) the ever-present danger of delayed chloroform poisoning.

1. It is said that status lymphaticus cannot be recognised ante-mortem. I do not agree. In my experience it never does to give much, if any, chloroform vapour to persons under 30 years of age who (1) have some enlargement of the thyroid gland with fulness of the episternal notch ; (2) have a slow pulse with no spring or rebound in it; and (3) are either not apparently nervous or are in a mournfully depressed state. They may seem to be excellent subjects for anæsthetics in every other way, but if they present those signs they are always the worst. But there is no particular danger and not much anxiety if the C.E. mixture be limited in quantity and followed by open ether. 2. Delayed chloroform poisoning can (only) be prevented.

I beg leave to endorse Dr. Barton's remarks on the value of C.E.-ethyl chloride-C.E. sequence for rapid (and safe) induction, such value being obvious in the case of children and nerrous women, and enhanced by the fact that patients who are caused to "go under" quickly also " come round" quickly-and pleasantly - a point of some importance in private work.

I am, Sir, yours faithfully,

London, S.W., August 3rd, 1909

Donald J. MUNRo.

\section{AN INDEPENDENT MEDICAL PROFESSION IN INDIA.}

\section{To the Editor of THE LANCET.}

SIR,-The question of fostering the development of an indigenous medical profession involves two considerations, inter-related indeed, but yet vitally distinct. The first and incomparably the more important is, what ought and what can Government do to promote the growth of a body of medical practitioners trained indeed in Government colleges of medicine but dependent thereafter, not on Government employment, but on private practice amongst their fellow countrymen. The second and much narrower question is to what extent it is possible or desirable to utilise native agency in Government medical work, whether legal, educational, clinical, or research. It is on the solution of the former question that depends the gradual extinction of that farrago of Hippocratic pathology, occultism, and empiricism that constitutes the stock-in-trade of the hakim, the vaid, and the Ojha, and that leads to the vast mass of suffering, loss of health, and premature death which all must deplore who know anything of medical practice in the East. In this matter the policy of Government has been to provide a Western medical education of a higher and lower grade and to establish far and wide charitable dispensaries staffed by native practitioners primarily for the direct relief of suffering amongst the poor but also as an object-lesson to the well-to-do in the benefits of Western medicine. The lesson has been but too well learnt and the effect has unfortunately been the pauperisation by free medical aid of a vast number of the comparatively well-to-do and the direct discouragement of the private practitioner. Our medical diplomates, like those in arts and law, now look for a career almost solely to Government employ. The remedy is difficult to indicate but will probably be found along two main lines, the imposition of some check on abuse of charity together with some restriction of unqualified practice. But whatever be the remedy it cannot be too much emphasised that this is the important and outstanding question-namely, the status and prospects of the private practitioner-and any solution of our second question must be judged mainly by its probable bearing on the irst.

Let us turn now to the second question. It is admitted that up to the present the most responsible Government work, whether connected with research, with medical education, or with forensic medicine, has been entrusted to members of the Indian Medical Service. And this is so for reasons which must be held to be to a great extent still valid. For fruitful research the worker must be in close touch with the trend of scientific thought and experiment. At present India is a back-water far removed from the main current of scientific activity. The worker in India therefore must be in close touch with Europe and that in the nature of things the Indian graduate cannot yet be in any sufficient measure. Nor, it must be confessed, is there any evidence as yet of any aptitude in the Indian mind for original research in this realm of thought.

In the same way, until there arises something like a national school of medicine in India, it is necessary that the principal teaching should be in the hands of those who are by association and training fitted to be the channel through whom new methods and new views from more advanced centres may find their way into Indian practice. And even a European-trained Indian graduate does not fulfil this condition. More important than original training as a student is often renewed contact with the Western schools. Any attempt unduly to curtail the influence of European teaching in the medical schools of India will inevitably lead to stagnation, if not retrogression. That important medicolegal work should be largely in the hands of Europeans. depends on the same cause that leads Government to retain the principal judicial posts largely in the bands of the Civil Service. While cordially admitting the great. improvement in knowledge, ability, and honesty of the Indian medical practitioner, as of the native magistrate, we may still maintain that it will be long yet before the average native practitioner, however skilful, can be trusted to be as independent as his European confrère.

One reason, perhaps the most important reason, for the existence of the Indian Medical Service in its civil branch is apparently considered unworthy even of mention-namely, to afford medical aid to the European officers of Government and their families. Apart from any statutory right which such civil servants may be able to urge, it is obvious that morally one of the first duties of any civilised Government in a tropical, semi-civilised country is to afford its servants such assistance in sickness as they would be able to command at home-just as the parallel duty is recognised of assisting to provide the ordinances of religion.

It must be remembered that the qualifications of the vast majority of native practitioners are not such as would entitle them to registration in the United Kingdom. Even were their qualifications above reproach, the difference in social customs and manner of life of the two races is such as will always entitle the European civil servant, and more especially his family, to the services of a medical officer of his own class and colour. But what are "the more important civil surgeoncies" to which it is proposed to appoint natives? Precisely those where there are the largest official European communities and in which, whatever the Secretary of State and his advisers may think, their own civil servants will undoubtedly and most justly insist on having a European medical attendant of their own class.

I forbear to dwell on the effect on the service of any attempt to carry these views into effect. But it is sufficiently obvious to anybody who knows anything of the feeling of the service as to the already greatly diminished advantages of civil employ, that if only to the more isolated stations, where social amenities and professional prospects are least and unpaid drudgery greatest, are appointments to be open, there will be the greatest difficulty in filling even this numerically restricted cadre from the ranks of the service. Government would be better advised to devote its attention to the encouragement of the private medical practitioner, on the one hand, and, in the sphere of State medicine, to the crying need of a properly organised native sanitary service. Between the two all the surplusage of Indian-trained graduates may be for many a year to come usefully absorbed. Nor should the rewards and honours in these spheres be beneath the deserts of even the most distinguished. July 28th.
I am, Sir, yours faithfully,

FURLOUGH. 